\title{
Alfons Gregori*
}

\section{Mniejsze wśród regionalnych: literatury arańska i asturleońska w kontekście rozwoju języków współurzędowych w Hiszpanii**}

DOI: http://dx.doi.org/1 0.12775/LC.2019.024

\begin{abstract}
Streszczenie: Praca analizuje dwa pochodzące ze współczesnych czasów przykłady literatur tworzonych w językach mniejszościowych, niemających oficjalnego statusu na całym Półwyspie Iberyjskim, a mianowicie literatury arańskiej i asturleońskiej. Przedstawiona w artykule analiza została przeprowadzona na podstawie teorii polisystemu, która pozwoliła na wykazanie niskiego stopnia autonomii obu literatur - z nieidentycznych powodów - wobec mocniejszych systemów wspólfunkcjonujących na tym samym obszarze. Omawiana przez nas literatura przedstawiona zostanie w świetle polityki językowej stosowanej w Val d’Aran, Asturii i Leónie, przy szczegółowym zarysowaniu kontekstu politycznego i kulturowego tych regionów. Zaprezentowana zostanie również krytyczna panorama sytuacji socjolingwistycznej panującej w tych regionach, która to sytuacja związana jest oczywiście z dynamiką gospodarki oraz wpływów politycznych. W stosunku do instytucji administracyjnych i rynku wydawniczego analizuje się stan organów promujących język i literaturę arańską i asturleońską oraz produkcję książek jako wskaźnika słabości tych systemów literackich. Omawiane są także aspekty tożsamościowe - związane z obrazem tych terytoriów w zbiorowym wyobrażeniu wypływającym $\mathrm{z}$ ich usytuowania geograficznego - $\mathrm{w}$ zestawieniu $\mathrm{z}$ rodzajem literatury pisanej $\mathrm{w}$ arańskim i asturleońskim. Z powyższego wynika, że literatura asturleońska i literatura arańska posiadają dzisiaj niski stopień realnej autonomii wobec innych, silniejszych systemów literackich obecnych w ich obszarach autochtonicznych, czyli hiszpańskiego i częściowo galicyjskiego w przypadku literatury asturleońskiej oraz katalońskiego i hiszpańskiego w przypadku literatury arańskiej.
\end{abstract}

Słowa kluczowe: literatura asturleońska, literatura arańska, polityka językowa, języki w Hiszpanii

\footnotetext{
* Katalonista prowadzący badania wokół literatury fantastycznej, teorii literatury, gender studies, współczesnej muzyki popularnej i krytyki przekładu literackiego. Koordynuje działalnością Centrum Studiów Katalońskich na Uniwersytecie im. Adama Mickiewicza w Poznaniu.

E-mail: alfons@amu.edu.pl | ORCID: 0000-0003-0121-2876.

** Tę pracę chciałbym zadedykować Izaro Goirienie, byłej lektorce języka baskijskiego i pasjonatce inności językowej. Dziękuję dr Annie Skoneckiej za pomoc przy korekcie językowej.
} 


\title{
The Smaller Among the Regional: Aranese and Astur-Leonese Literatures in the Context of Development of Co-Official Languages in Spain
}

\begin{abstract}
This paper analyses two contemporary examples of literatures written in minority languages which are not official in the whole area of Iberian Peninsula, and namely the literatures in Aranese and Astur-Leonese. In this analysis, the conceptualization of polysystem theory has been applied, to the conclusion that both literatures suffer a low extent of autonomy facing the more powerful systems co-existing in the areas under consideration, although in each case this state of affairs is caused by different factors. The literatures under consideration will be presented in the light of the language policies applied in Val d'Aran, the Principality of Asturias and the province of León, with a detailed outline of their political and cultural context, as well as a critical panorama of the sociolinguistic situation prevailing in those regions, which is influenced by economical and political factors. In relation to the institutions and the publishing market, the units promoting the Aranese and Astur-Leonese languages and literatures on the one hand and the production of books written in these languages on the other are analysed as indicators of the weakness suffered by both these literary systems. Identity aspects that are related to the collective image of these territories due to their geographical location are also discussed in comparison with the type of literature that is being written in Aranese and Astur-Leonese. Ultimately, both Aranese and Astur-Leonese literary systems have today a low degree of real autonomy against other, stronger ones present in their respective autochthonous areas, i.e. Spanish and, partially, Galician systems in the case of Astur-Leonese literature, and Catalan and Spanish systems in the case of Aranese literature.
\end{abstract}

Keywords: Astur-Leonese literature, Aranese literature, language policy, languages in Spain

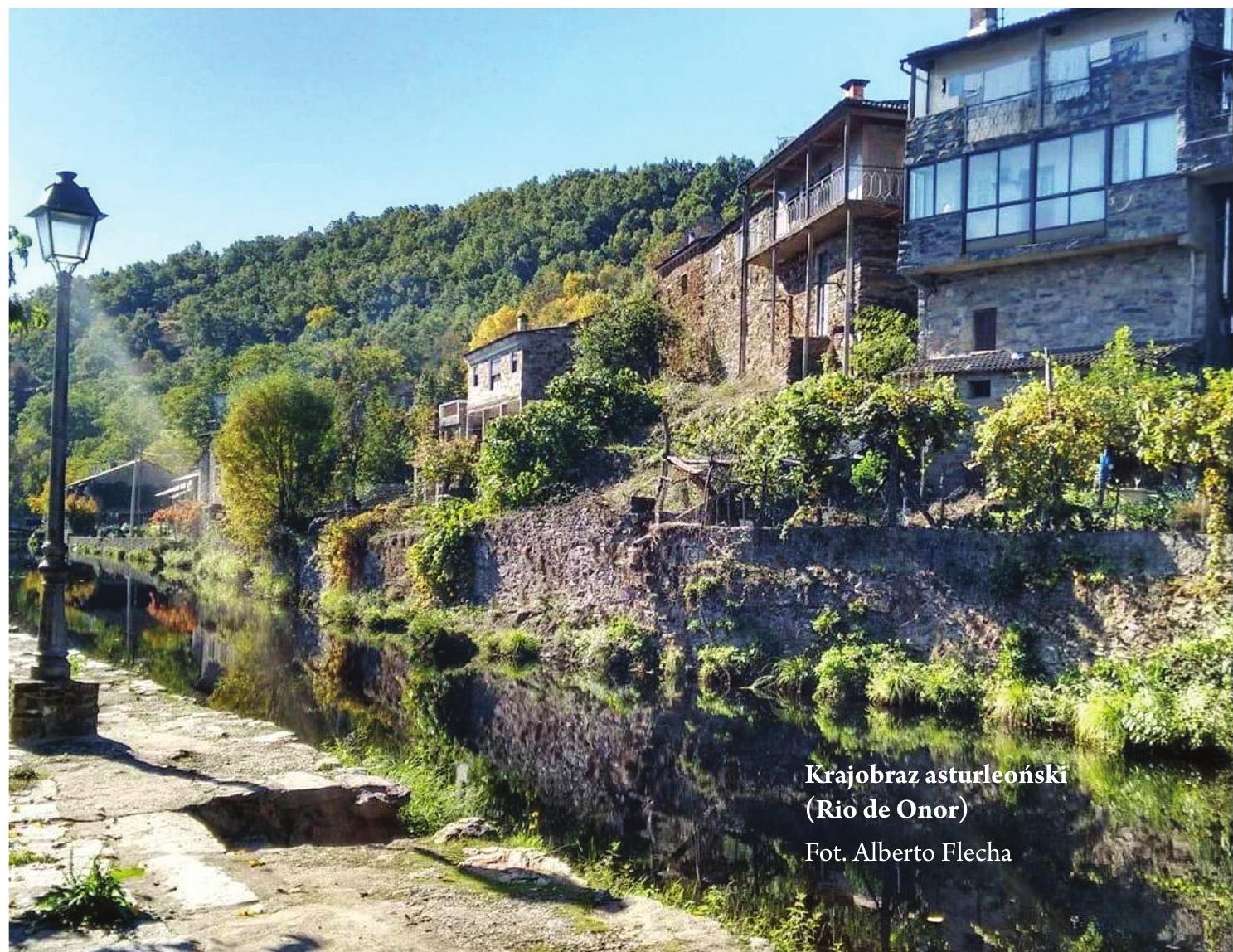


lutym 2017 roku odbyła się trzecia edycja konferencji naukowej pt. „Literatury Mniejsze" Europy Romańskiej, organizowana przez Instytut Filologii Romańskiej Uniwersytetu im. Adama Mickiewicza w Poznaniu. Tytuł wydarzenia niekoniecznie nawiązuje do wielkości określonego języka i jego literatury, lecz raczej do pojęcia wykorzystanego przez Gilles’a Deleuze’a i Félixa Guattariego w rozprawie wokół dzieła Franza Kafki (1975), aby „ujawnić subwersywny charakter pisania i usłyszeć inny głos w obrębie wspólnego języka" (Loba et al. 2012b: 7). Podczas trzech edycji konferencji przedstawiono prace dotyczące m.in. literatur romańskich powstałych na terenie małych państw europejskich, takich jak Belgia, czy niewiększościowych literatur romańskich powstałych na terenie średnich czy dużych krajów, takich jak Włochy czy Hiszpania. W nich obywatele posługują się językami o stosunkowo niewielkiej liczbie użytkowników, m.in. rumuńskim, katalońskim, galicyjskim, sycylijskim czy korsykańskim ${ }^{1}$. Należy podkreślić, że żaden z prezentowanych do tej pory referatów ani artykułów opublikowanych w tomach monograficznych nie zajmował się jednak problematyką dwóch „mniejszych literatur” rozwijających się na terytorium hiszpańskim poza głównymi obowiązującymi tam systemami literackimi. Mamy tu na myśli literaturę arańską ${ }^{2}$, tworzoną w wariancie języka okcytańskiego używanego w katalońskiej comarce ${ }^{3}$ znajdującej się w pirenejskiej dolinie Val d’Aran, oraz literaturę asturleońską, mającą swe korzenie w regionach Asturii i starego królestwa Leónu (przede wszystkim w obecnej prowincji Leónu, ale wcześniej także w prowincji Zamory i Salamanki) ${ }^{4}$, jak też w małym regionie Portugalii, szczególnie w miejscowości Miranda do Douro. Kolejnym „mikro-językiem” romańskim, w którym ukazują się książkowe publikacje, jest aragoński. Spośród wszystkich języków zakorzenionych terytorialnie w Hiszpanii aragoński cechuje się najmniejszą liczbą wydanych pozycji, stając się równocześnie najmniej widocznym językiem w jakimkolwiek obszarze publicznym.

W pracy poświęconej konceptowi literatury mniejszej Kwaterko odróżnia trzy typy sytuacji literatury peryferyjnej:

Pierwsza [sytuacja] dotyczy literatur geograficznie usytuowanych na pograniczu dominującego systemu literackiego. Przykładem mogą tu być literatury Europy frankofońskiej, takie jak

\footnotetext{
1 Warto dodać, iż w Polsce zostały opublikowane liczne artykuły omawiające literatury katalońską lub galicyjską w takich czasopismach, jak „Studia Iberystyczne” (UJ), „Estudios Hispánicos” (UWr) , ,Studia Romanica Poznaniensia” (UAM) czy „Itinerarium” (UW). Artykuły te nierzadko wynikają z prac prezentowanych na konferencjach naukowych (np. Encuentros). Jednak z uwagi na to, że większość tych prac jest napisana w języku hiszpańskim, katalońskim lub galicyjskim, polski czytelnik ma do nich ograniczony dostęp.

2 W swojej publikacji z 2012 roku Katarzyna Wojtowicz zwraca wprawdzie uwagę na trudną obecnie sytuację literatury okcytańskiej, skupiając się jednak jedynie na twórczości literackiej powstałej w południowej Francji, przez co pominięta zostaje literatura tworzona w tym języku w Val d’Aran, we włoskich Valadas Occitanas czy w księstwie Monako. Z drugiej zaś strony, w języku polskim termin „aranejski” stosuje się również w odniesieniu do wariantu okcytańskiego używanego w Val d'Aran.

3 W Katalonii system podziału terytorialnego na prowincje ma charakter czysto administracyjny. Podział ten został uchwalony w XIX wieku przez władze hiszpańskie wedle wzoru francuskich départements, bez odróżnienia terenów o odmiennych tradycjach kulturowych, historycznych, dialektalnych, handlowych. Mówiąc o tym terytorium, bardziej adekwatne wydaje się użycie terminu comarques, odnoszącego się od wielu wieków do podziału terytorialnego katalońskojęzycznych obszarów Półwyspu Iberyjskiego i obecnej Francji.

${ }^{4}$ Istnieje grupa językoznawców, którzy nie zgadzają się z uznaniem statusu języka asturleońskiego. Poglądy badaczy takich jak Manuela Alvara, José Mondéjara oraz Pilar Garcíi Mouton przedstawia w swojej publikacji José Enrique Gargallo Gil (2004: 29-30).
} 
belgijska czy szwajcarska [...]. Druga ogólna sytuacja określa literatury nazywane „regionalnymi” lub „dialektalnymi”, które tworzą podgrupy cieszące się nawet względną autonomią, ale które nie są w pełni uznane przez centrum za prawomocne (np. literatura katalońska w obrębie Europy romańskiej). Trzecia sytuacja cechuje produkcję literacką uznaną za marginalną bądź ze względu na uprawianie popularnych gatunków i form gatunkowych $[\ldots]$, bądź też - choć redukcja ta wyraźnie dziś łagodnieje - ze względu na rasę, pleć kulturową czy orientację seksualną pisarzy [...] (Kwaterko 2012: 14-15).

Autorzy decydujący się publikować swoją twórczość w języku asturleońskim ${ }^{5}$ czy arańskim, czyli tworzyć literaturę w ramach drugiej sytuacji peryferyjnej według teorii Kwaterki, próbują zaistnieć w cieniu skonsolidowanych w różnym stopniu dominujących systemów literackich Hiszpanii. Największym z nich jest system literacki kastylijski czy hiszpański, obecny na hiszpańskich terenach Półwyspu Iberyjskiego, Wyspach Kanaryjskich oraz na Balearach, będący jedynym językiem urzędowo obowiązującym w całej Hiszpanii ${ }^{6}$. Kolejny system literacki to kataloński, rozpowszechniony szczególnie w Katalonii, regionie walenckim, Andorze i na Balearach oraz w mniejszym stopniu w Katalonii Północnej (Rosselló, Conflent, Vallespir, Capcir, Alta Cerdanya), aragońskim Pasie Zachodnim (Franja) oraz Alghero (na Sardynii). W poczet skonsolidowanych literatur w Hiszpanii można włączyć także twórczość w języku galicyjskim, którego system literacki rozwija się przede wszystkim w Galicji, zaś w minimalnym stopniu w Asturii, Zamorze czy Leónie, oraz w języku baskijskim, obecnym w Baskonii, czyli we wspólnotach autonomicznych Euskadi i Nawarze oraz we francuskiej części Kraju Basków.

Wykorzystywane przez nas pojęcie systemu literackiego wywodzi się z teorii polisystemu proponowanej przez izraelskiego badacza Itamara Even-Zohara, bliskiej koncepcji pola literackiego Pierre’a Bourdieu (2007) lub wcześniejszej semiotyki kultury Jurija Łotmana $(1977)^{7}$. W swoich publikacjach Even-Zohar (1990: 9-44) podkreśla konieczność badania w literaturze współzależności elementów funkcjonujących i pojmowanych jako nachodzące na siebie wzajemnie siatki, na które składają się producenci, produkty, konsumenci, rynki, instytucje itd. W tym sensie, jak twierdzi José Lambert (1999), systemy literackie nigdy nie są autonomiczne i nie rozwijają się wyłącznie w narodach, do których są przypisane. Odpowiedniość teorii polisystemu jako ramy konceptualnej dla naszej analizy wynika z jej rzetelności i skuteczności w podejściu do literackich studiów porównawczych, szczególnie w społeczeństwach, w których można zaobserwować funkcjonowanie (także w sferze literackiej) przynajmniej dwóch języków.

Chyba jednym z najważniejszych osiągnięć teorii polisystemu, a również może jednym z powodów jej szerokiej akceptacji, było odnowienie w niej założeń na temat związków między „)ęzykiem”, „literaturą" i „tożsamością kulturową”. Prowadziło to do natychmiastowego zakwestionowania „literatur narodowych”. Była to jedyna podstawa teoretyczna, która w taki sposób podeszła do zjawiska wzajemnych oddziaływań między systemami literackimi, dzięki czemu

\footnotetext{
5 Język ten był historycznie określany pejoratywnym terminem bable.

6 Cele i tematyka tego artykułu nie pozwalają na wyszczególnienie problematyki związanej z systemami literackimi działającymi w innych krajach hiszpańskojęzycznych, z kontynentem amerykańskim na czele, oraz z Barceloną i Madrytem w Hiszpanii, jako istotnymi kastylijskojęzycznymi ośrodkami wydawniczymi.

7 W porównaniu z wymienionymi teoriami systemowymi pojęcie instytucji literackiej postulowane przez Jacques'a Dubois (1978) podlega fundamentalnym ograniczeniom merytorycznym.
} 
wykazała ona, że możliwe jest wytłumaczenie dynamicznego funkcjonowania literatury w kulturze i społeczeństwie ${ }^{8}$ (Iglesias Santos 1999b: 17).

Główny cel tej pracy stanowi przedstawienie polskiej publiczności obu mniej znanych rzeczywistości kulturowych, asturleońskiej i arańskiej, za pomocą twórczości literackiej powstałej w tych językach. Omawiana przez nas literatura zostanie przedstawiona w świetle polityki językowej stosowanej w Val d’Aran, Asturii i Leónie, przy szczegółowym zarysowaniu kontekstu politycznego i kulturowego tych regionów.

Aktualna sytuacja asturleońskiego i arańskiego jasno wskazuje, że należą one do grona języków zagrożonych. Diagnoza ta nie wynika jednak z wyznaczników opracowanych przez Stephena Maya (2001: 4), adekwatnie opisujących sytuację większości zagrożonych języków: w przypadku analizowanych przez nas języków sytuacja jest inna, albowiem nie posługują się nimi politycznie i społecznie marginalizowane lub podporządkowane grupy etniczne i narodowościowe. Choć literatury arańska i asturleońska są pozbawione skonsolidowanego systemu literackiego, ich języki posiadają oficjalne instytucje zajmujące się normatywizacją: są to z jednej strony powstała w 1980 roku Academia de la Llingua Asturiana, a z drugiej Institut d'Estudis Aranesi (IEA), od 2014 roku autorytet językowy wariantu arańskiego ustalonego zgodnie z zasadami gramatyki okcytańskiej Loísa Alibèrta, chętnie współpracujący z innymi instytucjami na rzecz ustalania norm języka okcytańskiego?.

Poza tymi interesującymi podobieństwami wybór wspomnianych wyżej języków jako tematu pracy wynika przede wszystkim z różnic, które umożliwiają ich ciekawą i konstruktywną analizę porównawczą. Choć literatura asturleońska jest tworzona na terenach o znacznie większej powierzchni niż Val d’Aran, język asturleoński nie został uznany oficjalnie jako urzędowy w regionach, gdzie jeszcze posługuje się nim część społeczeństwa, a mianowicie w Asturii i Leónie ${ }^{10}$. Warto zaznaczyć jednakże, iż w 1998 roku uchwalono ustawę dotyczącą używania i promocji asturyjskiego przez parlament autonomiczny w Asturii. Jest to jeden z zabiegów gwarantujących możliwość posługiwania się asturleońskim w oficjalnych sytuacjach oraz promujących i wspierających nauczanie tego języka i jego popularyzację w społeczeństwie (zob. Noticias Jurídicas 2017) ${ }^{11}$. Optymistyczne głosy - oparte wyłącznie na szacunkowych obliczeniach czy mało wiarygodnych ankietach o niskiej liczbie respondentów - przypisują asturleońskiemu 550 tysięcy użytkowników (zob. Ethnologue 2017a), podczas gdy arańskiemu mniej niż pięć tysięcy (zob. Generalitat de Catalunya 2015: 107-112; por. Ethnologue 2017b).

8 Jeśli nie wskazano inaczej, przekłady cytatów pochodzą od autora artykułu.

9 Ustalenie owych norm dzieli środowisko specjalistów - choć większość z nich opowiada się za koniecznością wprowadzenia standardu okcytańskiego, czyli kodu supraregionalego (tzw. occitan referencial lub occitan larg general), socjolingwiści zajmujący się Val d’Aran podkreślają potrzebę kodyfikacji własnego wariantu arańskiego, co miałoby pozwolić jego użytkownikom na łatwiejsze utożsamienie się z formalną wersją swojego języka. Na ten temat zob. pracę Carrery (2011: 9-15, 120-123), która zawiera gramatykę oraz słownik i occitan referencial okcytańskiego z Val d'Aran.

10 Hiszpańska Konstytucja, uchwalona w 1978 roku po śmierci dyktatora gen. Franco, w punkcie 2 artykułu 3 przyznaje wspólnotom autonomicznym prawo do ustanawiania w swoich statutach języków autochtonicznych jako języków urzędowych: „[...] pozostałe języki hiszpańskie [inne niż kastylijski] są również językami urzędowymi w odpowiednich wspólnotach autonomicznych, zgodnie z ich statutami" (Biblioteka Sejmowa RP 2017). Język asturleoński jest wprawdzie wspominany w przedmowie asturyjskiego Statutu Autonomicznego (1981), lecz nie pociąga to za sobą żadnych prawnych następstw.

11 García Arias (2004: 253) sądzi, że ustawa ta jest niewystarczająca, ponieważ nadaje zbyt ważną rolę inicjatywie politycznej samorządu oraz nie obowiązuje państwowej administracji publicznej w Asturii. 
Wyżej wspomniana inicjatywa prawna $\mathrm{w}$ połączeniu $\mathrm{z}$ rewitalizacją oraz sympatią Asturyjczyków wobec swojego języka (dotyczy to szczególnie niskich klas społecznych) sprawiły, iż przedstawione na początku XXI wieku prognozy związane z przyszłością języka asturleońskiego nie były zbyt dramatyczne (García Arias 2004: 246). Warto dodać, że pomimo istnienia Academii de la Llingua Asturiana już od czasów zmiany systemu politycznego w Hiszpanii na demokratyczny intelektualiści, aktywiści i świadomi użytkownicy nie zdołali wywalczyć oficjalnego uznania i rzeczywistego poparcia dla języka asturleońskiego ze strony instytucji publicznych (których działania ograniczyły się do pustych obietnic oraz niewielkiej pomocy finansowej). Być może z tego powodu instytucja ta nie tylko zajmuje się normami językowymi i leksykografią, lecz działa jako instytut promujący język, kulturę i literaturę asturleońską, podobnie jak hiszpański Instituto Cervantes, kataloński Institut Ramon Llull czy baskijski Etxepare Euskal Institutua ${ }^{12}$. Oznacza to, że Academia ma sekcje do spraw literatury, etnografii i kultury oraz organizuje Dni Literatury Asturyjskiej. W ramach tych dodatkowych funkcji nie tylko przeprowadza konkursy literackie, teatralne i kinematograficzne, lecz także działa jako główne wydawnictwo w tym języku. Wyjaśnienie całego procesu socjolingwistycznego dotyczącego asturleońskiego nie jest tutaj możliwe; warto jednakże wspomnieć o czynniku, który wpłynął na osłabienie statusu społecznego oraz prestiżu intelektualnego języka asturleońskiego. Badania prowadzone w północnozachodnich terenach Hiszpanii, gdzie posługiwano się mowami romańskimi innymi niż język galicyjski, charakteryzowały się tendencyjnością centralistycznie nastawionych uczonych. Ich nacjonalistyczna ideologia hiszpańska ${ }^{13}$ doprowadziła do podzielenia asturleońskiego obszaru językowego oraz do używania odmiennych terminów w odniesieniu do wariantów tego języka. W rzeczywistości natomiast „leoński ${ }^{14} \mathrm{i}$ asturyjski są dwoma glottonimami określającymi rzeczywistość językową, która w istocie jest taka sama na obu terytoriach, gdzie się mówi w języku [asturleońskim]” (Asociación Cultural Faceira 2012: 7).

Również w przypadku okcytańskiego sytuacja w Val d’Aran nie wygląda na niepokojącą: pomimo względnie niskiej liczebności użytkowników tego języka, od 2006 roku punkt 5 artykułu 6 katalońskiego Statutu Autonomicznego uznaje go za język współurzędowy na całym terytorium Katalonii, stosując w praktyce status ten do terenów Val d’Aran (zob. Parlament de Catalunya 2012: 13) - od 1990 tylko w tej comarce arański posiadał taki status $^{15}$. W praktyce jednak posługiwanie się arańskim w ogólnokatalońskiej sferze publicznej, np. podczas krótkich emisji nadawanych przez katalońskie radio publiczne, ma charakter incydentalny i czysto symboliczny. Wyjątkową sytuację stanowiło kontrowersyjne referen-

12 Warto wspomnieć o zasadniczych dla asturleońskiego instytucjach języka i kultury galisyjskiej geograficznie bliższych Asturii: Secretaría Xeral da Política Lingüística de Xunta de Galicia, Consello da Cultura Galega, Real Academia Galega.

13 M.in. Gramática Asturiana Juana Junquery Huergo została wydana dopiero w 1991 roku, a jego słownik -z drugiej połowy XIX wieku - wciąż pozostaje nieopublikowany (García Arias 2004: 246).

14 Warto dodać, że językowe normy postulowane przez Academię de la Llingua Asturiana zostały wykorzystane przez pisarzy tworzących swoje utwory literackie w dialekcie leońskim (Asociación Cultural Faceira 2012: 7).

15 Status języka asturleońskiego w regionie Trás-os-Montes e Alto Douro w Portugalii - gdzie znajduje się miasto Miranda do Douro, od którego wywodzi się również glottonim „mirandyjski” - jest nieco bliższy do statusu arańskiego w Katalonii, albowiem mirandyjski został uznany oficjalnie przez Republikę Portugalską w 1999 roku. Nawet liczba mieszkańców w tym portugalskim regionie jest podobna do liczby mieszkańców w Val d’Aran, która znajduje się poza obszarem politycznym głównego regionu okcytańskiego, tak jak mirandyjski wobec hiszpańskiego regionu asturleońskiego. Właśnie z powodu portugalskiej przynależności owego dialektu asturleońskiego nie będzie on omawiany w tej pracy, która skupia się na temacie języków używanych na terenie Hiszpanii. 
dum niepodległościowe odbywające się w Katalonii 1 października 2017 roku, w trakcie którego, pod ogromną presją polityczną, medialną i policyjną władz hiszpańskich, arański stanowił jeden z języków używanych na karcie do głosowania. Ten fakt stał się zatem narzędziem międzynarodowej promocji tego języka.

Krótkie diachroniczne porównanie Asturii z regionem o udanym procesie odzyskania statusu języka urzędowego i wysokiego prestiżu społecznego, jakim jest Katalonia, pozwoli nam ukazać ważne różnice między dwoma przypadkami tzw. języków regionalnych w okresie współczesnym w Hiszpanii. Średniowieczne struktury państwowe regionów Katalonii i Asturii opierały się na dokumentach pisanych w języku autochtonicznym (lub łaciną). Uwarunkowania historyczne sprawiły, że w przypadku Asturii zjawisko pisania dokumentów państwowych w języku lokalnym zostało zapoczątkowane znacznie później niż na terenie Katalonii. W XIII wieku Asturię dołączono bowiem - wraz z Leónem - do Królestwa Kastylii, odgrywającego kluczową rolę w procesie rekonkwisty. $\mathrm{Z}$ tego też powodu język asturleoński został zastąpiony przez język kastylijski, czyli obecny hiszpański, tracąc swój wcześniejszy status (zob. Mar-Molinero 2000: 20) ${ }^{16}$; dla porównania, Katalonia i inne terytoria katalońskojęzyczne dopiero pod koniec XV wieku stały się częścią unii dynastycznej, która dała początek państwu hiszpańskiemu w epoce wczesnej nowożytności. Teksty literackie $\mathrm{w}$ asturleońskim były w średniowieczu praktycznie nieobecne, podczas gdy katalońska literatura przeżywała wtedy swój czas rozkwitu. Mogą o tym świadczyć chociażby liczne dzieła w języku katalońskim, od tekstów Ramona Llulla - wedle wielu badaczy twórcy katalońskiego języka literackiego - z końca XIII wieku do powieści Tirant lo Blanc, napisanej w latach sześćdziesiątych XV stulecia i wychwalanej w Don Kichocie Cervantesa (2014: 141).

Na przestrzeni XIX wieku region asturyjski - w którym do końca XX stulecia znajdowały się najbogatsze złoża węgla kamiennego w całej Hiszpanii (por. Jaros 1975: 14) - stał się jednym z liczących się obszarów w procesie industrializacji tego kraju. W Katalonii jeszcze wcześniej zaczęła rozwijać się sieć małych i średnich fabryk włókienniczych, które wraz z późniejszym baskijskim przemysłem metalurgicznym i hutniczym funkcjonowały jako główne siły napędowe procesu modernizacji socjoekonomicznej na Półwyspie Iberyjskim. W odróżnieniu od Katalonii elity lokalne w Asturii nie stały się kulturalnym i politycznym motorem do odzyskania prestiżu historycznego języka ich przodków. Elita asturyjska rozumiała modernizację i industrializację jako uwalnianie się od elementów kojarzonych jako wiejskie i rustykalne. Za jeden z nich uznano język asturyjski, postrzegany jak bezwartościowa gwara. Język kastylijski zastąpił go w większości formalnych sytuacji komunikacyjnych, podobnie jak galicyjski w Galicji lub kataloński w niektórych rejonach terytorium walenckiego.

Język okcytański był historycznie zakorzeniony przede wszystkim w południowych regionach Francji ${ }^{17}$, w których doszło do wykształcenia się ważnych inicjatyw przeciwstawiających się tendencjom uniformizacji i centralizacji kraju ${ }^{18}$. Powstałe tam ruchy oporu

16 Szul (2009: 293) zwraca uwagę na nazwy regionów Europy Zachodniej - takie jak „Katalonia” czy „Asturia” sugerujące „związek z dawniej istniejącym państwem”.

17 Forma „prowansalski”, bardziej popularna w Polsce, dotyczy jednego z głównych dialektów języka okcytańskiego, używanego w czasach średniowiecznych przy tworzeniu poezji trubadurskiej.

18 Inicjatywy te obejmowały ruchy etnoregionalne bądź nacjonalistyczne dążące do zachowania odrębności kulturowo-językowej regionów i ludów peryferyjnych we Francji - bretońskiego, baskijskiego, katalońskiego, itp. Szul (2009: 179) przypomina, że „najsilniejszy z nich to ruch oksytański obejmujący regiony południowe zróżni- 
obejmowały jednak tylko tereny należące do Francji, pozostawiając bez swojej protekcji inne terytoria, do których można zaliczyć np. Val d’Aran. Osłabienie języka autochtonicznego prawie doprowadziło do jego zniknięcia ze sfery publicznej: pod koniec XV wieku okcytański stawał się stopniowo językiem zamkniętym w domenach prywatnych we Francji, a od drugiej połowy XIX wieku cały jego obszar używania był intensywnie wypierany na rzecz dominującego języka francuskiego. Czy w Hiszpanii arański rozwijał się analogicznie w cieniu katalońskiego? Raczej nie. Z jednej strony, prowansalski był odmianą okcytańskiego dostosowaną do poezji lirycznej w średniowieczu, gdyż katalońska literatura zaczęła się kształtować w tym czasie. Z drugiej strony, podobieństwo między starokatalońskim a ówczesnym prowansalskim prowadziło później do ich błędnego utożsamienia ${ }^{19}$. W podręcznikach historii literatury katalońskiej rozdziały omawiające czasy średniowieczne zawierały informacje o poezji prowansalskiej katalońskich autorów ${ }^{20}$. Natomiast wariant gaskoński, do którego należy arański, jest najbardziej odmienny od pozostałych okcytańskich ${ }^{21}$. Cecha ta utrudniała kojarzenie go z pojawiającą się w literaturze historyczną formą języka okcytańskiego ${ }^{22}$ oraz dostrzeżenie jego związków $\mathrm{z}$ katalońskim.

Równocześnie należy wziąć pod uwagę, że w Val d’Aran współistnieją trzy języki urzędowe: hiszpański, kataloński i arański. W rzeczywistości pierwszy z nich jest najpowszechniej używany w tej comarce, albowiem 55\% populacji porozumiewa się zwykle po kastylijsku, natomiast około $16 \%$ mówi po katalońsku, a $17 \%$ po okcytańsku (zob. Generalitat de Catalunya 2015: 109). Suils et al. (2004: 201-202) podają dwa kluczowe czynniki wpływające na zmniejszenie się procentu użytkowników arańskiego w ostatnich dekadach: nagła zmiana w gospodarce lokalnej (praktycznie całkowity zanik sektora rolniczego na rzecz sektora usług) oraz regres w przekazywaniu języka arańskiego następnym pokoleniom, zwłaszcza w przypadku małżeństw mieszanych. Wobec raczej rzadkiego posługiwania się językiem arańskim, niepozwalającego Arańczykom żywić nadziei na jego zachowanie, bardzo korzystna dla nich jest hegemoniczna w Katalonii ideologia określana po angielsku jako linguistic preservationism. Ideologia ta wspiera ochronę mniejszych języków oraz okazywanie solidarności z ich użytkownikami. Zostało to jasno wyrażone w tzw. katalońskiej ustawie o języku okcytańskim, aranejskim w Val d’Aran ${ }^{23}$. W hiszpańskich regionach jednojęzycznych spotyka się często negatywne podejścia do katalońskiego, baskijskiego, galicyjskiego czy asturleońskiego za sprawą przesądów przekazywanych w rodzinie, wśród przyjaciól, w mediach i w instytucjach publicznych.

cowanego obszaru langue d'oc". Polski autor natomiast nie wspomina w swojej panoramicznej monografii o unikatowej sytuacji językowej w Val d'Aran.

19 Do czasu odrodzenia literatury katalońskiej w XIX wieku termin llemosí (limuzyński) był używany jako synonim języka katalońskiego w tekstach literackich i formalnych, chociaż odnosił się on do historycznej krainy Limousin, a równocześnie do jednego z wariantów języka okcytańskiego.

20 Nie dodano do podręczników natomiast ani informacji dotyczących twórczości literackiej arabskojęzycznych autorów, którzy zamieszkiwali obecne tereny katalońskojęzyczne, ani informacji na temat pisarzy, którzy tworzyli w języku kastylijskim od epoki wczesnej nowożytności.

21 Arański należy do wschodniego wariantu gaskońskiego dialektu.

22 Jak stwierdził ceniony specjalista Pèire Bèc (1986: 44), „język gaskoński stanowi w całości okcytańsko-romańskiej jednostkę [...] językową całkiem oryginalną [...]. Od średniowiecza jest uznawany jako lengatge estranh [dziwny język] w stosunku do koinê trubadurów".

${ }^{23}$ "Sens interwencji ustawodawczej jest spójny z wartościami i celami w obronie różnorodności językowej inspirującymi katalońską politykę językową. Równocześnie, poprzez promocję tych samych wartości i celów w Hiszpanii i Europie [kataloński] Parlament pragnie brać udział w ochronie i rozpowszechnianiu okcytańskiej spuścizny językowej, obecnej także w innych terytoriach" (Generalitat de Catalunya 2010). 
Natomiast w Katalonii nie istnieje wrogi dyskurs wobec okcytańskiego oraz kultury arańskiej - zauważalna jest raczej ignorancja ze strony wielu Katalończyków oraz ogólnie Hiszpanów. Instytucje lokalne w Val d'Aran - nierzadko z poparciem samorządu katalońskiego - działają nie tylko w dziedzinie edukacji, lecz także promują rozwój arańskiego systemu literackiego. Między innymi wspierają finansowo publikacje arańskich utworów (bajki, tłumaczenia książek dla dzieci, słowniki itd.) oraz starają się mobilizować użytkowników arańskiego do publikowania swojej twórczości literackiej, np. poprzez adresowany do młodzieży konkurs im. Condò Sambeata czy konkurs Aran dla pisarzy już dorosłych (Generalitat de Catalunya 2015: 115-116).

Takie inicjatywy są niezbędne w kontekście rynku wydawniczego, na którym pojawia się niewiele arańskojęzycznych utworów. Analiza danych uwzględnionych w rejestrze publikowanych w Hiszpanii książek (Gobierno de España 2017) pozwala zaobserwować pewien brak ciągłości związany z literaturą wydawaną w języku arańskim. Mianowicie, o ile w drugiej dekadzie XXI wieku w skali rocznej zarejestrowano wydanie około 10 utworów, o tyle w roku 2004 i 2005 opublikowano zaledwie cztery pozycje ${ }^{24}$. Największa liczba publikacji ukazała się w 2016 roku, kiedy wydano ich 13. W dodatku większość tych książek to podręczniki szkolne, literatura młodzieżowa czy dziecięca, tłumaczenia z katalońskiego lub innych języków oraz prace leksykograficzne, frazeologiczne i etnograficzne. Przy tym literatura piękna opublikowana w języku arańskim nierzadko ma kształt antologii opowiadań czy wierszy. Wśród nich specjalną wartość przedstawia opublikowana w 1999 roku antologia tekstów pod redakcją Jèpa de Montoyi (Montoya 1999) - wyjątkowość tej publikacji wynika nie tylko z zawartych w niej tekstów literackich, lecz również z jej nadrzędnego celu - zobrazowania historii języka arańskiego. Oznacza to, jak stwierdza Montoya (ibid.: 1269), że kompilacja pt. Vademecum aranense: antologia de tèxtes en aranés (gascon des nautes sorces dera Garona, sègles XII-XX) przedstawia ewolucję języka od XII do końca XX wieku ${ }^{25}$.

Jak podkreśla Sans Socasau (2008: 45), mieszkańcy Val d’Aran są świadomi swojej okcytańskości, mimo korzystania przez nich z katalońskich czy hiszpańskich wytworów kultury oraz niewielkiej liczby przekładów na język arański istniejącej na rynku okcytańskim. Co również znamienne, nawet w przypadku konkursu literackiego Es Talauries, oferującego zwycięzcy najbardziej szczodrą na świecie nagrodę finansową wśród wszystkich konkursów utworów napisanych w języku okcytańskim, liczba zgłaszanych propozycji pozostaje bardzo niewielka. Większość prac jest napisana w wariancie arańskim, ich rozpowszechnienie natomiast - znikome w porównaniu z utworami w języku hiszpańskim czy katalońskim (ibid.: 45, 49). Nagrodę finansuje lokalna administracja katalońskiej prowincji, do której należy Val d’Aran, czyli Lleida. W noszącej tę samą nazwę stolicy tej prowincji ma swoją siedzibę wydawnictwo Pagès Editors, publikujące w ostatnich latach największą liczbę książek po arańsku lub o tematyce arańskiej.

24 Niedoskonałość baz danych wynika głównie z niepoprawnego katalogowania książek.

25 Książka zawiera również teksty pochodzące z gaskońskiego rejonu Comminges, ponieważ redaktor uważa, że ten obszar stanowi continuum językowe z Val d'Aran (Montoya 1999: 1270). Z tego samego powodu Carrera (2010: 34) stwierdza, że arański należy do gaskońskiego wschodniopirenejskiego, tak jak comengés czy coseranés. Pobudki użycia terminu „arański” w kontekście omawianego wariantu językowego można uznać zatem za polityczne (Carrera 2008: 9). 
W pracy poświęconej rozwojowi literatury asturleońskiej na przestrzeni wieków García Arias (2004: 245) podkreśla, że pierwsza antologia wydana w tym języku ukazała się w XIX wieku, wraz z odrodzeniem literatury katalońskiej, mimo iż, jak zaznacza, „Należy zauważyć, że literaturę nowoczesną po asturyjsku tworzono nieprzerwanie od XVII w., gdy tworzył ją pierwszy znany poeta - Antón de Marirreguera, aż do naszych czasów”. Głównym specjalistą w zakresie historii literatury asturleońskiej jest Ramos Corrada, który w 1995 roku opublikował w języku asturleońskim pierwsze wydanie syntezy dotychczasowej wiedzy o literaturze asturyjskiej z perspektywy tradycyjnego literaturoznawstwa historiograficznego (zob. Ramos Corrada 2002a). Tekst był częścią większej publikacji, a mianowicie raportu o stanie języka asturleońskiego pt. Informe sobre la llingua asturiana. Kilka lat później ten ciekawy przegląd historii literatury asturleońskiej został znacznie rozszerzony w opracowaniu monograficznym pod redakcją tego samego Ramosa Corrady (2002b). Obie prace wydała Academia de la Llingua Asturiana. W czasach współczesnych w języku asturleońskim rozwijały się różne gatunki literackie proza, poezja, teatr, esej. Działo się to szczególnie po hiszpańskiej wojnie domowej oraz w okresie tzw. Surdimientu („powstania”), który rozpoczął się od pojawienia Conceyu Bable w 1974 roku, pod koniec dyktatury frankistowskiej. Jest to ruch promujący posługiwanie się językiem asturleońskim w każdym obszarze i rejestrze komunikacji językowej przy dynamizowaniu rynku kulturowego w regionie za pomocą tworzenia muzyki, prasy i książek po asturleońsku.

Choć Academia de la Llingua Asturiana oraz Ediciones Trabe są nadal uznawane za głównych wydawców w języku autochtonicznym Asturii, publikacja książek w XXI wieku okazuje się dużo bardziej zróżnicowana na obszarze asturleońskim niż w Val d’Aran, gdy uwzględni się wielość gatunków, w jakich jest publikowana asturleońska literatura, oraz firm wydawniczych, funkcjonujących niczym satelity Academii oraz Ediciones Trabe, zaangażowanych w rewitalizację języka asturleońskiego. Mimo to w ostatnich latach doszło jednak do zmniejszenia liczby wydawanych pozycji: podczas gdy w pierwszej dekadzie XXI wieku produkcja wahała się wokół stu książek rocznie - w 2003 roku nawet 129 - to od 2012 spadek liczby nowych publikacji jest ewidentny: ukazało się tylko 51 pozycji w 2013 oraz 41 w 2016 roku (Gobierno de España 2017). Jednym z głównych czynników spadku były prawdopodobnie efekty kryzysu gospodarczego ogarniającego całą Hiszpanię, który rzutował na drastyczne cięcia w finansach publicznych - również tych lokalnych.

Pisząc o produkcji literackiej w omawianych tu językach, musimy brać pod uwagę dwa istotne, dosyć paradoksalne czynniki. Po pierwsze, istnieje związek między tożsamością asturleońską oraz arańską a przyrodą otaczającą miejscowości w Val d’Aran i w Asturii. Przez przyrodę w szczególności rozumiemy panującą w tych regionach zieleń, a także specyfikę ich rzeźby jako terenów górskich, odróżniającą je od płaskich i bardziej suchych terenów kastylijskiej Mesety. Góry Picos de Europa i Montes de León w Asturii i Leónie, jak również Montes de León i Pireneje w Val d’Aran do pewnego stopnia izolują od siebie tamtejsze miasteczka i wsie. Po drugie, asturleońska czy arańska twórczość powstaje w stosunkowo niewielkiej odległości od potężnych ośrodków literackich i kulturalnych, które w oczywisty sposób wpływały na styl oraz gatunki stosowane przez twórców w interesujących nas językach lokalnych. Tak jak wspomniano we wcześniejszej części artykułu, śmierć dyktatora Franco oraz proces demokratyzacji państwa hiszpańskiego pozwoliły na prawne uznanie języków mniejszościowych oraz 
na rozwój ich instytucjonalnej promocji. To właśnie w tych okolicznościach doszło do wykształcenia się grupy autorów w Leónie i Galicji - czyli w językowym obszarze asturleońskiego oraz w jego okolicy - tworzących zgodnie z trendem postmodernistycznym. Ich przykład stanowią m.in. Luis Mateo Díez czy José María Merino w Leónie, piszący jednak po hiszpańsku jako swoim językiem rodzimym, lub Manuel Rivas w Galicji po galisyjsku. Gdy mówimy natomiast o literaturze arańskiej, to tworzona jest ona w regionie, gdzie większość wydarzeń kręci się wokół Barcelony, czyli jednej z głównych stolic wydawniczych w świecie hiszpańskojęzycznym. W tym kontekście autorzy piszący w języku katalońskim i kastylijskim stanowią kreatywną oraz bardzo różnorodną siłę, która często wykorzystuje nowe, zachodnie trendy literackie. Wpływy takich tendencji są zauważalne również w przypadku nielicznych pisarzy publikujących w języku arańskim, dzięki kontaktom tych autorów ze studentami z Val d’Aran zamieszkałymi w stolicy Katalonii czy z Arańczykami pracującymi w Barcelonie i okolicach.

W wyniku wyżej opisanych czynników, analizując literaturę arańską oraz asturleońską, możemy zaobserwować interesujący, skrajny kontrast z jednej strony między utworami wywodzącymi się z tradycji ruralistycznej i egzystencji na wsi, portretującymi - a często idealizującymi - środowisko naturalne, a z drugiej, dziełami eksperymentalnymi czy bardzo nowoczesnymi, które biorą udział w odnowieniu panoramy literackiej na Półwyspie Iberyjskim. Spoglądając na ten problem ponownie z perspektywy socjolingwistycznej, warto podkreślić, że cechy potrzebne wedle Levy do zachowania zagrożonego języka nie mogą zostać odnotowane w przypadku języka asturleońskiego i arańskiego:

Gdy mamy do czynienia z kilkoma setkami czytelników i pisarzy posługującymi się geograficznie skoncentrowanym językiem, gdy książki i czasopisma są powszechnie publikowane w celu komercyjnym - i publikowane są przez ludzi usiłujących sprzedać książki i czasopisma, a nie przez tych wydających je jako część językowego planu - wtedy prawdopodobieństwo zniknięcia tego języka zdaje się dramatycznie spadać (Levy 2003: 237).

Kontrast między nowoczesnością a „wiejskim duchem” znacząco wpływa na dynamikę rozwoju mniejszościowych systemów literackich arańskiego i asturleońskiego. Należy pamiętać natomiast, że proces tego rozwoju jest nadal w toku. W obecnej sytuacji literatura asturleońska i literatura arańska mają niski stopień realnej autonomii wobec innych, silniejszych systemów literackich obecnych w ich obszarach autochtonicznych, czyli hiszpańskiego i częściowo galicyjskiego w przypadku literatury asturleońskiej oraz katalońskiego i hiszpańskiego w przypadku literatury arańskiej.

\section{Bibliografia}

Asociación Cultural Faceira 2012. Xurdir: guía gramatical de leonés. La Bañeza: Asociación Cultural Faceira.

Bèc, Pèire 1986. La langue occitane. Wydanie 5. Paris: PUF.

Biblioteka Sejmowa RP 2017. Konstytucja Hiszpanii z dnia 27 grudnia 1978. Tytut wstępny. http:// libr.sejm.gov.pl/tek01/txt/konst/hiszpania.html [15.09.2017]. 
Bourdieu, Pierre 2007. Reguły sztuki. Geneza i struktura pola literackiego. Przełożył Andrzej Zawadzki. Kraków: Universitas.

Carrera, Aitor 2008. Entre dues frontères. Estudis de lingüística occitana [Między dwoma granicami: badania oksytańskiego językoznawstwa]. Lleida: Pagès.

-2010. Gramatica aranesa [Gramatyka języka arańskiego]. Lleida: Pagès.

_2011. L'occità: gramàtica i diccionari bàsics. Occità referencial i aranès [Język okcytański: gramatyka i słownik podstawowe]. Lleida: Pagès.

Cervantes, Miguel de 2014. Przemyślny szlachcic Don Kichotz Manchy. PrzełożyłWojciech Charchalis. Poznań: Rebis.

Deleuze, Gilles, Félix Guattari 1975. Kafka. Pour une littérature mineure. [Paris:] Les Editions de Minut.

Dubois, Jacques 1978. L'institution de la littérature: introduction à une sociologie. Bruxelles: Bernand Natnan i Labor.

Ethnologue 2017a. „Asturian”. W: Gary F. Simons, Charles D. Fennig (red.). Ethnologue: Languages of the World. Dallas: SIL International. https://www.ethnologue.com/language/ast [30.08.2017]

2017b. „Occitan”. W: Gary F. Simons, Charles D. Fennig (red.). Ethnologue: Languages of the World. Dallas: SIL International. Publikacja zamieszczona na stronach: https://www.ethnologue.com/language/oci [30.08.2017].

Even-Zohar, Itamar 1990. „Polisystem Theory”. Poetics Today 11 (1): 9-94.

García Arias, Xosé Lluis 2004. „La llengua asturiana: present i perspectives” [Język asturyjski: stan obecny i perspektywy]. W: Pradilla Cardona 2004. 245-262.

Gargallo Gil, José Enrique 2004. „España plurilingüe: la diversitat lingüística i la diversitats dels lingüistes” [España plurilingüe: różnorodność językowa i różnorodności językoznawców]. W: Pradilla Cardona 2004. 25-51.

Generalitat de Catalunya 2010. Llei 35/2010, d'1 d'octubre, de l'occità, aranès a l'Aran [Ustawa 35/2010, z 1 października, dot. okcytańskiego, arańskiego w Val d’Aran]. DOGC, 29 października.http://dogc.gencat.cat/ca/pdogc_canals_interns/ [01.09.2017].

2015. Informe de política lingüística [Raport polityki językowej]. http://llengua.gencat.cat/web/.content/documents/informepl/arxius/IPL-2015.pdf [01.09.2017].

Gobierno de España 2017. Base de datos de libros editados en España. http:/ /www.mcu.es/webISBN/ buscarLibros.do [04.09.2017].

Iglesias Santos, Montserrat 1999a. La Teoría de los Polisistemas. Madrid: Arco/Libros.

1999b. „La Teoría de los Polisistemas como desafío a los estudios literarios”. W: Iglesias Santos 1999a. 9-20.

Jaros, Jerzy 1975. Zarys dziejów górnictwa weglowego. Warszawa-Kraków: Państwowe Wydawnictwo Naukowe.

Kwaterko, Józef 2012. „Literatura mniejsza: koncept, ideologia, możliwość tekstu”. W: Loba et al. 2012. 13-23.

Lambert, José 1999. „Aproximaciones sistémicas y la literatura en las sociedades multilingües”. W: Iglesias Santos 1999a. 53-70.

Levy, Jacob T. 2003. „Language rights, literacy, and the modern state”. W: Will Kymlicka, Alan Patten (red.). Language rights and political theory. Oxford: Oxford University Press. 230-249.

Loba, Mirosław, Barbara Łuczak, Alfons Gregori (red.) 2012a. „Literatury mniejsze” Europy romańskiej. Poznań: Wydawnictwo Naukowe UAM.

— 2012b. „Wstęp”. W: Loba et al. 2012. Pp. 7-9.

Łotman, Jurij 1977. Semiotyka kultury. Wybór i opracowanie Elżbieta Janus i Maria Renata Mayenowa. Warszawa: Państwowy Instytut Wydawniczy. 
Mar-Molinero, Clare 2000. The politics of language in the Spanish-speaking world: from colonisation to globalisation. London-New York: Routledge.

May, Stephen 2001. Language and minority rights: ethnicity, nationalism and the politics of language. Harlow, London: Longman Pearson Education.

Montoya, Jèp de (red.) 1999. Vademecum aranense: antologia de tèxtes en aranés (gascon des nautes sorces dera Garona, sègles XII-XX) [Vademecum aranense: antologia tekstów w języku arańskim (gaskońskim z wysokich źródeł rzeki Garonny, w. XII-XX)]. Val d’Aran: Conselh Generau d'Aran.

Noticias Jurídicas 2017. Ley 1/1998, de 23 de marzo, de uso y promoción del bable/asturiano. http:// noticias.juridicas.com/base_datos/CCAA/as-11-1998.html [25.09.2017].

Parlament de Catalunya 2012. Organic Act 6/2006 of the 19th July, on the Reform of the Statute of Autonomy of Catalonia. https://www.parlament.cat/document/cataleg/150259.pdf [30.08.2017].

Pradilla Cardona, Miquel-Àngel (red.) 2004. Calidoscopi lingüístic: un debat entorn de les llengües de l’Estat [Kalejdoskop językowy: debata wokół języków w państwie hiszpańskim]. Barcelona: Octaedro-EUB.

Ramos Corrada, Miguel 2002a. „Lliteratura asturiana” [Literatura asturyjska]. W: Academia de la Llingua Asturiana. Informe sobre la llingua asturiana [Raport wokół języka asturyjskiego]. Uviéu: Academia de la Llingua Asturiana. 69-76.

— (red.) 2002b. Historia de la lliteratura asturiana [Historia literatury asturyjskiej]. Uviéu: Academia de la Llingua Asturiana.

Sans Socasau, Jusèp Loís 2008. Occitan en Catalonha [Język okcytański w Katalonii]. Lleida: Pagès.

Suills Subirà, Jordi, Àngel Huguet Canalís, Cecilio Lapresta Roy 2004. „Entre la prosperitat econòmica i el manteniment de la llengua autòctona a la Vall d'Aran" [Między gospodarczym dobrobytem a zachowaniem autochtonicznego języka w Val d'Aran]. W: Pradilla Cardona 2004. Barcelona: Octaedro-EUB. 201-213.

Szul, Roman 2009. Język, naród, państwo: język jako zjawisko polityczne. Warszawa: Wydawnictwo Naukowe PWN.

Wójtowicz, Katarzyna 2012. „Trudna teraźniejszość literatury okcytańskiej”. W: Loba et al. 2012. 219-226. 